Pesq. Vet. Bras. 37(12):1531-1536, dezembro 2017 DOI: $10.1590 / \mathrm{S} 0100-736 \mathrm{X} 2017001200028$

\title{
Hematological findings and factors associated with feline leukemia virus (FeLV) and feline immunodeficiency virus (FIV) positivity in cats from southern Brazil ${ }^{1}$
}

\author{
Fernanda V.A. da Costa ${ }^{2}$, Stella de F. Valle ${ }^{3 *}$, Gustavo Machado ${ }^{4}$, Luís G. Corbellini ${ }^{5}$, \\ Elisa M. Coelho ${ }^{2}$, Rafael B. Rosa ${ }^{3}$ and Félix H.D. González ${ }^{3}$
}

\begin{abstract}
Costa F.V.A., Valle S.F., Machado G., Corbellini L.G., Coelho E.M., Rosa R.B. \& González F.H.D. 2017. Hematological findings and factors associated with feline leukemia virus (FeLV) and feline immunodeficiency virus (FIV) positivity in cats from southern Brazil. Pesquisa Veterinária Brasileira 37(12):1531-1536. Laboratório de Análises Clínicas Veterinárias, Faculdade de Veterinária, Universidade Federal do Rio Grande do Sul, Av. Bento Gonçalves 9090, Porto Alegre, RS 91540-000, Brazil. E-mail: stella.valle@ufrgs.br

Using a retrospective study, 493 cats tested for FeLV and FIV were selected for analysis of the association between hematologic findings and positivity at immunoassay test. Individual and hematologic variables were assessed considering the influence of results using univariate and multivariate logistic regression analysis. Out 153 of the 493 cats were positive for FeLV (31\%), 50 were positive for FIV (10.1\%) and 22 were positive for both FIV and FeLV (4.4\%). Multivariate analysis detected significant associations between FeLV infection and age below 1 year $(\mathrm{p}=0.01)$, age from 1 to 10 years $(\mathrm{p}=0.03)$, and crossbreed $(\mathrm{p}=0.04)$. Male cats were more likely to be FIV-positive $(\mathrm{p}=0.002)$. Regarding hematological changes, FeLV-positive cats have higher odds to anemia, leukopenia and lymphopenia than FeLV-negative cats. FIV-positive cats are more likely to have anemia than negative. Identification of associated factors related to animal status and correlation of hematological disorders with infection by retroviruses in cats could be useful for detecting these retroviral diseases in cats.

INDEX TERMS: Leukemia virus, immunodeficiency virus, cats, anemia, leukopenia, cytopenias, feline retroviruses, southern Brazil.
\end{abstract}

RESUMO.- [Achados hematológicos e fatores associados a positividade pelo vírus da leucemia felina (felv) e vírus da imunodeficiência felina em gatos do sul do Brasil.] Através de um estudo retrospectivo, 493 gatos testados para FeLV e FIV foram selecionados para análise da associação

\footnotetext{
${ }^{1}$ Received on April 17, 2017.

Accepted for publication on April 28, 2017.

${ }^{2}$ Departamento de Medicina Animal, Faculdade de Veterinária, Universidade Federal do Rio Grande do Sul (UFRGS), Av. Bento Gonçalves 9090, Porto Alegre, RS 91540-000, Brazil.

${ }^{3}$ Departamento de Patologia Clínica Veterinária, Faculdade de Veterinária, Universidade Federal do Rio Grande do Sul (UFRGS), Av. Bento Gonçalves 9090, Porto Alegre, RS 91540-000, Brazil. *Corresponding author: stella.valle@ufrgs.br

${ }^{4}$ Department of Veterinary Population Medicine, College of Veterinary Medicine, University of Minnesota, 1365 Gortner Avenue, St. Paul, MN 55108, USA.

${ }^{5}$ Departamento de Medicina Veterinária Preventiva, Faculdade de Veterinária, Universidade Federal do Rio Grande do Sul (UFRGS), Av. Bento Gonçalves 9090, Porto Alegre, RS 91540-000, Brazil.
}

entre as alterações hematológicas e a positividade no teste imunoenzimático. Variáveis individuais e hematológicas foram consideradas para verificar a influência dos resultados utilizando análise de regressão logística univariada e multivariada. Um total de 153 de 493 gatos avaliados foram positivos para o FeLV (31\%), 50 foram positivos para o FIV $(10,1 \%)$ e 22 foram positivos para FIV e FeLV $(4,4 \%)$. Análise multivariada detectou uma associação significativa entre a infecção pelo $\mathrm{FeLV}$ e a idade abaixo de 1 ano $(\mathrm{P}=0,01)$, idade entre 1 a 10 anos $(\mathrm{P}=0,03)$ e raça mista $(\mathrm{P}=0,04)$. Gatos machos foram mais predispostos a serem positivos para FIV $(\mathrm{P}=0,002)$. Com base nas alterações hematológicas, gatos positivos para o FeLV tem maior odds para apresentar anemia, leucopenia e linfopenia que os negativos. Gatos positivos para FIV possuem maiores chances de apresentarem anemia que os gatos negativos. A identificação dos fatores associados à infecção relacionados ao perfil do animal e a correlação com os distúrbios hematológicos com a infecção, pode ser útil para detecção das doenças retrovirais em gatos. 
TERMOS DE INDEXAÇÃO: Leucemia, imunodeficiência, gatos, anemia, leucopenia, citopenias, retroviroses felinas, Rio Grande do Sul.

\section{INTRODUCTION}

The feline leukemia virus (FeLV) and feline immunodeficiency virus (FIV) are retroviruses with worldwide distribution that affect domestic cats and have the ability to replicate in various tissue types, including bone marrow (Hartmann 2011, 2014). FeLV is the more pathogenic virus of the two, causing tumors (especially lymphoma) and suppression of bone marrow activity and of the immune system, leading to secondary infections (Hartmann 2012). FIV causes acquired immunodeficiency syndrome, increasing the risk of opportunistic infections, neurological diseases and tumors (Hartmann 2012). Risk factors to FeLV infection include young age and living in environments with high population density and poor hygiene (Lutz et al. 2009). Adult male free-living cats have the greatest susceptibility to become infected by FIV (Hosie et al. 1989).

Suppression of bone marrow activity can occur in both infections, but is more common and more severe in cats infected with FeLV (Gleich et al. 2009, Hartmann 2012, Hartmann 2014). Hematologic changes described in FeLV-positive cats include non-regenerative, regenerative, or aplastic anemia; persistent, cyclical, or transient neutropenia; platelet abnormalities and panleukopenia (Hartmann 2011). Acute phase of FIV infection is characterized by mild neutropenia and, at a later stage, variable cytopenia, especially lymphopenia (Shelton \& Linenberger 1995).

These viral diseases can be diagnosed using screening tests such as immunochromatography or ELISA to detect the p27 protein of the FeLV capsid and FIV-specific antibodies and can be confirmed with tests such as viral isolation, direct immunofluorescence (FeLV), Western blot (FIV) or PCR, which detects the proviral DNA in circulating leukocytes (Hosie et al. 1989, Dunham \& Graham 2008, Lutz et al. 2009). In clinical practice, the immunochromatographic test is highly recommended as a screening test because of its high sensitivity and specificity (Hosie et al 1989, Lutz et al. 2009, Hartmann 2011).

The aims of this retrospective study were to identify hematologic abnormalities and associated factors to infection by FeLV and FIV in domestic cats.

\section{MATERIALS AND METHODS}

Study design and selection of sample of cats. A retrospective study was conducted using hematological and biochemical data obtained from 493 domestic cats that were tested from 2010 to 2014 for FIV and FeLV at a Veterinary Teaching Hospital (Federal University of Rio Grande do Sul, Brazil). Sex, age and breed were recorded for all animals. Cats aged less than 1 year were defined as young, cats aged 1 to 10 years were defined as adults, and cats over 10 years old were defined as elderly. Animals with prior diagnoses of retroviruses and those that had had blood transfusions before the study were excluded. The study was conducted in accordance with the Federal University of Rio Grande do Sul Ethics Committee's guidelines.

Laboratory parameters. To hematologic parameters, EDTA blood samples were analyzed in automated hematology counters
(ABC Vet, ABXMicros, Horiba; or Procyte Dx, IDEXX Laboratories) using hematocrit by the micro-hematocrit technique (Sigma Laborzentrifugen, Germany) as reference method. Differential WBC counts were conducted by manual evaluation of blood smears stained with Diff-Quik, using an optical microscope. The serum samples were used to biochemical analyses such as albumin (Alb), total protein (TP), creatinine (Creat), alanina transaminase (ALT), and alkaline phosphatase (ALP) were performed in an automated analyzer (CM 200, Wiener, Argentina), using commercial kits and following the manufacturers' recommendations. Aggregate reticulocyte counts were conducted manually (Tvedten \& Moritz 2010) not in all anemic samples. For all results, hematological and biochemical parameters were compared to laboratory reference values. For all variables, values within and below the reference range were considered for analysis as categorized variables. Anemia was defined as hematocrit lower than 24\% (reference interval: 24 to $45 \%$ ).

All cats selected to this study were serum tested for FIV and FeLV with ELISA (SNAP FIV/FeLV Combo Test, IDEXX Laboratories), which detects the presence of the FeLV p27 antigen (sensitivity of $98.6 \%$ and specificity of $98.2 \%$ ) and FIV antibodies (sensitivity of $93.5 \%$ and specificity of $100 \%$ ) (Hartmann et al. 2007). All of the cats in the sample were tested only once and inconclusive results were considered negative and excluded to study.

Statistical analysis. Two models were constructed for statistical analysis to test the hypothesis of association between FIV/FeLV serology and host-specific information. The outcome variable for the first model was the results of the FeLV test and the outcome variable for the second model was the results of the FIV test. An unconditional logistic regression approach was used. Age, sex and breed were analyzed as univariate variables. All terms were checked for collinearity, and no significant correlations were found. All variables with $\mathrm{P}<0.20$ in the univariate analysis were considered for multivariate analysis and p-values less or equal to $5 \%$ were once more considered significant. All two-way interactions between variables in the final models were assessed for significance at the $5 \%$ level. All hematological and biochemical data were analyzed descriptively, taking into account the results for FeLV and FIV tests.

Additionally, the relationships between hematological parameters and diagnoses of FeLV and/or FIV were analyzed. For this, the following variables were used as outcomes (dichotomized as described in 2.2) and measured using logistic regression, for which the cutoff was a p-value less or equal to $5 \%$ : hematocrit, hemoglobin, white blood cells count, neutrophils, total lymphocytes, eosinophils, platelets, TP, Alb, Crea, ALT and ALP.

\section{RESULTS}

A total of 485 cats were selected for the study and this population consisted of 228 males (46.2\%) and 257 females (52.1\%) with a median age of 3 years (range: 1 month to 18 years) (Table 1). The majority of cats in this study were crossbred (89.8\%). According to the univariate logistic regression, young cats (OR: 5.26, 95\% CI: 2.25-12.3) and crossbred cats (OR: 5.33, 95\% CI: 1.95-14.55) showed higher odds to be positive for FeLV (Table 1). In the multivariate analysis, young cats were 5.19 times the odds to be FeLV-positive than elderly cats. Similarly to FeLV-positive cats, FIV-positive adult cats showed odds of 3.22 of being seropositive compared to elderly cats. The odds of crossbred cats having the infection in comparison with purebred animals were 10. Sex was detected as an associated factor for FIV infection in both univariate and multivariate analy- 
Table 1. Univariate and multivariate analyses in determining factors associated with FeLV-positive $(n=153)$ and negative $(n=338)$ cats

\begin{tabular}{lcccccccc}
\hline Associated factors & \multicolumn{2}{c}{ FeLV-positive } & \multicolumn{2}{c}{ FeLV-negative } & \multicolumn{2}{c}{ Univariate analysis } & \multicolumn{2}{c}{ Multivariable analysis } \\
\cline { 2 - 8 } & $\mathrm{n}$ & $\%$ & $\mathrm{n}$ & $\%$ & $\mathrm{p}$-value & OR $(95 \% \mathrm{CI})$ & $\mathrm{p}$-value & OR $(95 \% \mathrm{CI})$ \\
\hline Age (years) & & & & & & & & \\
$<1$ (young) & 16 & 17.0 & 23 & 10.0 & 0.003 & $5.26(2.25-12.3)$ & 0.01 & $5.19(2.18-12.33)$ \\
$1-10$ (adult) & 71 & 6.0 & 153 & 66.8 & 0.02 & $3.51(1.74-7.07)$ & 0.03 & $3.22(1.58-6.54)$ \\
$>10$ (enderly) & 7 & 7.0 & 53 & 23.2 & - & - & - & - \\
Gender & & & & & & & & \\
Male & 84 & 55.6 & 173 & 52.1 & 0.47 & $0.86(0.58-1.27)$ & & \\
Female & 67 & 44.4 & 159 & 47.9 & - & - & & \\
Breed & 147 & 98 & 294 & 90.2 & 0.006 & $5.33(1.95-14.55)$ & 0.04 & $10.12(1.86-55.06)$ \\
$\quad$ Crossbred & 3 & 2 & 32 & 9.8 & & - & & - \\
Purebred & & & & & & & & \\
\hline OR = Odds ratio. & & & & & & & &
\end{tabular}

Table 2. Univariate and multivariate analyses in determining factors associated with FIV-positive $(n=50)$ and negative $(n=443)$ cats

\begin{tabular}{|c|c|c|c|c|c|c|c|c|}
\hline \multirow[t]{2}{*}{ Associated factors } & \multicolumn{2}{|c|}{ FIV-positive } & \multicolumn{2}{|c|}{ FIV-negative } & \multicolumn{2}{|c|}{ Univariate analysis } & \multicolumn{2}{|c|}{ Multivariable analysis } \\
\hline & $\mathrm{n}$ & $\%$ & $\mathrm{n}$ & $\%$ & p-value & OR $(95 \% \mathrm{CI})$ & p-value & OR $(95 \% \mathrm{CI})$ \\
\hline \multicolumn{9}{|l|}{ Age (years) } \\
\hline < 1 (young) & 2 & 5.2 & 37 & 13.0 & 0.21 & $0.40(0.10-1.59)$ & & \\
\hline $1-10$ (adult) & 30 & 76.9 & 194 & 68.3 & 0.32 & $1.17(0.56-2.43)$ & & \\
\hline > 10 (enderly) & 7 & 17.9 & 53 & 18.7 & & - & & \\
\hline \multicolumn{9}{|l|}{ Gender } \\
\hline Male & 36 & 73.5 & 221 & 50.7 & 0.002 & $2.69(1.54-4.68)$ & 0.003 & $2.69(1.54-4.68)$ \\
\hline Female & 13 & 26.5 & 215 & 49.3 & & - & & - \\
\hline \multicolumn{9}{|l|}{ Breed } \\
\hline Crossbred & 46 & 93.9 & 397 & 92.5 & 0.73 & $1.23(0.44-3.43)$ & & \\
\hline Purebred & 3 & 6.1 & 32 & 7.5 & & - & & \\
\hline
\end{tabular}

ses (Table 2). Male cats had had higher odds of being FIV-positive than females (OR: 2.69, 95\% CI: 1.54-4.68).

Overall, 153 (31\%) of the 485 cats were FeLV-positive (95\% CI: 27.0-35.3), and this subset had a median age of 2.3 years (range: 1.1 months to 14 years), 30.7\% (47/153) of them had anemia (Table 3 ) (Hematocrit $<24 \%$ ) and $56 \%$ of those for which aggregated reticulocytes were counted had a regenerative response (corrected aggregated reticulocyte count $<0.4 \%$ ). The white blood cells count (WBCs) results (Table 2) showed that $14.7 \%(22 / 153)$ of the FeLV-positive cats had leukopenia $\left(<5.0 \times 10^{3} / \mu \mathrm{l}\right)$ and a differential leukocyte count was not performed in 7 FeLV-positive samples because of severe leukopenia $\left(<1.0 \times 10^{3} / \mu \mathrm{l}\right)$. Neutropenia was observed in $11.6 \%$ (17/146) and lymphopenia in 39\% $(57 / 146)$. Thrombocytopenia $(<200.000 / \mu \mathrm{l})$ was observed in $42.2 \%$ of the FeLV-positive cats.

Fifty cats were FIV-positive (10\%; 95\% CI: 7.6-13.2), with a median age of 7 years (range: 4 months to 6 years), while $32 \%(16 / 50)$ of the FIV-positive cats were anemic (Table 4), 4\% were leukopenic and 35\% were thrombocytopenic. Twenty-two cats (4.4\%) were concomitantly FIV-positive and FeLV-positive (95\% CI: 2.8-6.7).

The odds of having anemia was $20 \%$ higher in FeLV-positive cats (OR: 1.20, 95\% CI: 1.13-1.29; p<0.001) than in FeLV-negative cats. Similarly, the odds of having leukopenia and lymphopenia were 8\% (OR: 1.08, 95\% CI: 1.03-1.14; $\mathrm{p}=0.001$ ) and 13\% higher (OR: 1.13, 95\% CI: 1.0-1.28; $\mathrm{p}=0.03$ ), in FeLV-positive cats, respectively. In FIV-positive cats, the odds of having anemia were $19 \%$ hi- gher (OR: 1.19, 95\% CI: 1.07-1.33; p<0.001) than in FIV-negative cats.

\section{DISCUSSION}

According to both of the statistical models applied (univariate and multivariate), cats with higher odds to be positive for FeLV were younger (less than 1 year old), which is in agreement with other reports (Arjona et al. 2000, Levy et al. 2006, Bande et al. 2012, Collado et al. 2012). In most cases, FeLV infected cats do not reach adulthood, since it is a disease that is associated with 2-3 years' survival (Chhetri et al. 2015). Furthermore, younger cats' immune systems are still immature and infection can occur via transplacental and transmammary transmission, infecting patients while still young (Lutz et al. 2009, Scherk et al. 2013). In present study, any influence from gender was considered as a factor associated with FeLV infection, which has been reported in previous studies that found males were more likely to be infected (Levy et al. 2006, Gleich et al. 2009, Bande et al. 2012). Other studies have also failed to identify associations between infection and gender (Bandecchi et al. 1992, Lee et al. 2002, Collado et al. 2012) probably because transmission of FeLV is not as strongly associated with cats' territorial behavior as FIV. Notably, in our study male cats had higher odds $(\mathrm{OR}=2.69)$ to be FIV-positive comparing with females, which is in agreement with most studies, which emphasize the importance of transmission during fights (Hosie et al. 1989, Arjona et al. 2000, Hartmann 2011, 2012, 2014, Scherk et al. 2013). Although mon- 
grel cats exhibited greater likelihood of infection than purebred cats, this data has little relevancy because the study population included very few purebred cats.

With regard to laboratory parameters, it can be obser- ved that the cats that were positive for retroviruses had more blood abnormalities and that those caused by FeLV are more severe than those associated with FIV. In retroviral infection, the pathogenic effect of the FeLV on the bone

Table 3. Descriptive analysis of hematological and biochemical parameters in FeLV-positive and negative cats

\begin{tabular}{|c|c|c|c|c|c|c|}
\hline \multirow[t]{2}{*}{ FeLV-positive } & \multicolumn{3}{|c|}{ FeLV-negative } & \multicolumn{3}{|c|}{$\mathrm{p}$-value } \\
\hline & $\mathrm{N}$ & Median & Range (min-max) & $\mathrm{N}$ & Median & Range (min-max) \\
\hline Red Blood Cells Count $\left(\times 10^{6} / \mu \mathrm{L}\right)$ & & & & & $>0.05$ & \\
\hline$<5$ & 48 & 2.57 & $4.22(0.75-4.97)$ & 30 & 3.09 & $4.05(0.7-4.75)$ \\
\hline $5-10.5$ & 103 & 7.42 & $5.44(5.02-10.46)$ & 281 & 8.21 & $5.45(5.01-10.46)$ \\
\hline Hemoglobin $(\mathrm{g} / \mathrm{dL})$ & & & & & $>0.05$ & \\
\hline$<8$ & 47 & 4.5 & $5.4(2.2-7.6)$ & 32 & 5.0 & $6.1(1.5-7.6)$ \\
\hline $9-15$ & 101 & 11.3 & $6.6(8.4-15)$ & 278 & 12.25 & $6.8(8.1-14.9)$ \\
\hline Hematocrit (\%) & & & & & $<0.001$ & \\
\hline$<24$ & 47 & 15 & $18(6-24)$ & 34 & 18 & $20(2-24)$ \\
\hline $24-45$ & 102 & 34 & $20(25-45)$ & 284 & 37 & $20(25-45)$ \\
\hline MCV (fL) & & & & & $>0.05$ & \\
\hline $39-55$ & 117 & 46.6 & $15.93(39.01-54.94)$ & 298 & 44.15 & $15.83(39-54.83)$ \\
\hline$>55$ & 35 & 63 & $40.9(55.2-96.1)$ & 23 & 60.56 & $59.21(55.07-114.28)$ \\
\hline MCHC (g/L) & & & & & $>0.05$ & \\
\hline$<31$ & 35 & 30 & $7.63(23.33-30.96)$ & 28 & 28.82 & $6.24(24.71-30.95)$ \\
\hline $31-35$ & 111 & 33.06 & $3.01(31.09-35)$ & 279 & 32.92 & $3.85(31.02-34.87)$ \\
\hline White Blood Cells Count $\left(\mathrm{x} 10^{3} / \mu \mathrm{l}\right)$ & & & & & 0.001 & \\
\hline$<5.0$ & 22 & 2.5 & $4.61(0.19-4.8)$ & 19 & 4.0 & $4.36(0.64-5.0)$ \\
\hline $5.0-19.5$ & 100 & 10.8 & $13.9(5.4-19.3)$ & 252 & 10.9 & $14.4(5.1-19.5)$ \\
\hline Total Neutrophils $\left(\mathrm{x} 10^{3} / \mu \mathrm{L}\right)$ & & & & & $>0.05$ & \\
\hline$<2.5$ & 17 & 0.98 & $2.22(0.28-2.5)$ & 14 & 1.9 & $1.94(0.55-2.49)$ \\
\hline $2.5-12.5$ & 89 & 6.91 & $9.55(2.69-12.24)$ & 320 & 6.48 & $9.81(2.59-12.40)$ \\
\hline Total lymphocytes $\left(\mathrm{x} 10^{3} / \mu \mathrm{L}\right)$ & & & & & 0.03 & \\
\hline$<1.5$ & 57 & 0.92 & $1.31(0.16-1.47)$ & 112 & 1.01 & $1.46(0.03-1.5)$ \\
\hline $1.5-7.0$ & 76 & 2.69 & $5.39(1.56-6.96)$ & 205 & 2.58 & $5.25(1.50-6.76)$ \\
\hline Platelets $\left(\mathrm{x} 10^{9} / \mu \mathrm{L}\right)$ & & & & & $>0.05$ & \\
\hline$<200$ & 41 & 100 & $189(11-200)$ & 44 & 180 & $187(13-200)$ \\
\hline $200-300$ & 22 & 245 & $84(206-290)$ & 86 & 268.5 & $95(205-300)$ \\
\hline Albumin (g/dL) & & & & & $>0.05$ & \\
\hline
\end{tabular}

Table 4. Descriptive analysis of hematological and biochemical variables in FIV-positive and negative cats

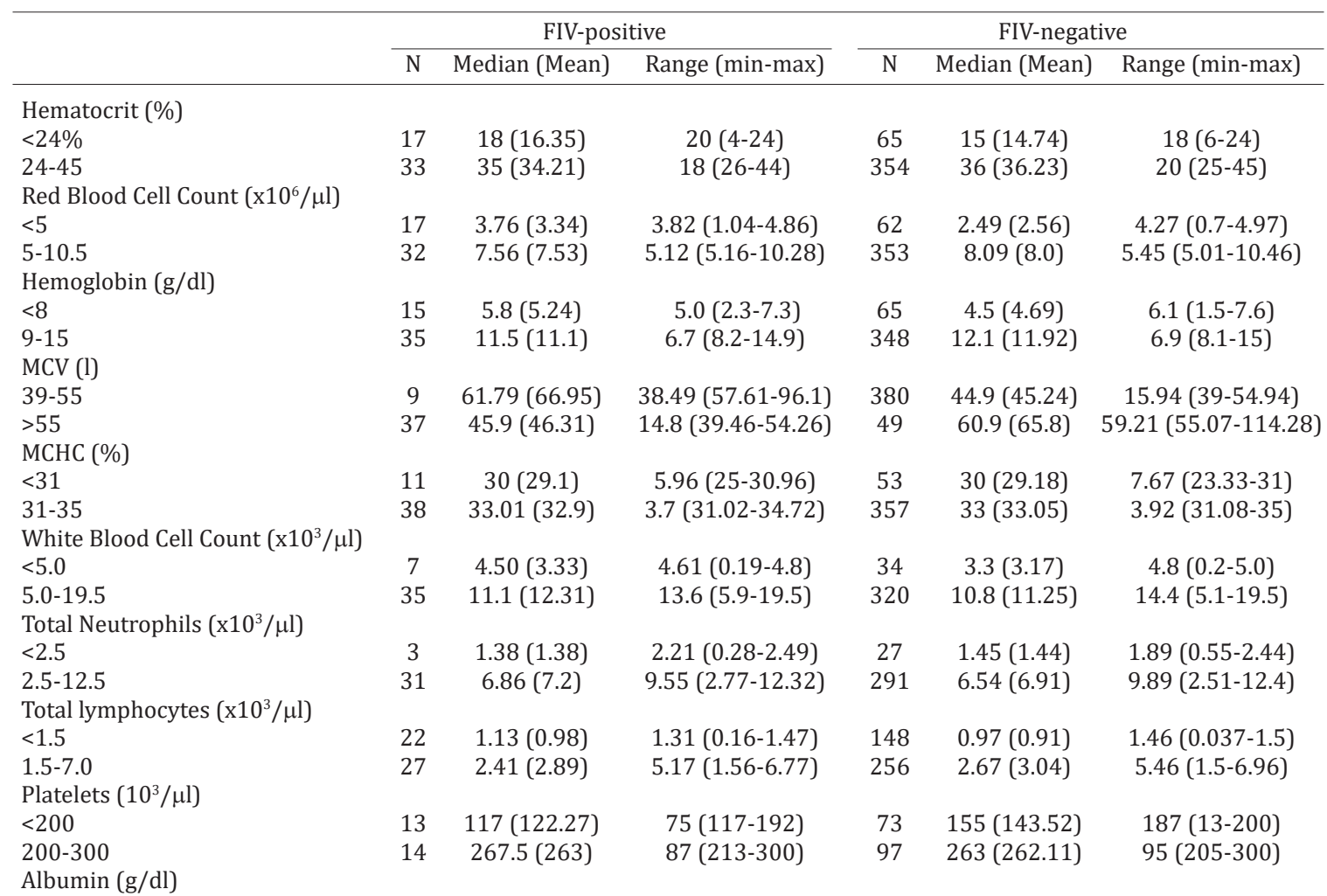


marrow is more marked and detrimental than the effects occasioned by FIV. In FeLV-positive cats, cytopenias can be attributed to bone marrow suppression associated with active viral replication in hematopoietic cells or in bone marrow structural cells (stroma and fibroblasts) that alters the microenvironment necessary for hematopoiesis (Hartmann 2011). These hematological changes have been associated with natural (Linenberger \& Abkowitz 1995, Gleich \& Hartmann 2009) and experimental (Hofmann-Lehmann et al. 1997) infections and are more evident in cats with clinical signs than in asymptomatic cats (Collado et al. 2012). Of the several blood alterations that are observed in FeLV-infected cats, anemia is considered the most common non-neoplastic complication in cats infected with retroviruses (Gleich \& Hartmann 2009), which may be the result of direct cytopathic effects on the bone marrow or caused by mechanism involved in a chronic inflammation. In these situations, replacement of the bone marrow with fibrous or neoplastic tissue could exist and the anemia may have immune-mediated origins (Gleich \& Hartmann 2009, Sykes 2010, Hartmann 2014).

The median hematocrit of the FeLV-positive cats in the present study was $14.5 \%$ and the univariate regression indicated that positive cats were $20 \%$ more likely to be anemic than negative cats. This result is relevant to clinical practice since that the anemia could be the single clinic signal in positive cats and could suggest the blood retroviral test when investigating causes of anemic condition. However, to anemia information it must be interpreted prudently considered that this anemia could be transient in FeLV infection and that erythroid hypoplasia is only related in cats infected with the FeLV-C subtype (Lutz et al. 2009).

The principal limitation of this study is that the regenerative response of bone marrow was not characterized because aggregated reticulocyte counts were not performed in all anemic cats. It is believed that $10 \%$ of anemia in FeLV infections is regenerative (Shelton \& Linenberger 1995), which could have an influence on monitoring and control of the clinical signs of the disease. In present study, 9 (64\%) out of the 14 anemic FeLV-positive cats that had aggregated reticulocytes counted and had reticulocytosis of varying degrees. This information is relevant in clinical practice because reticulocyte counts in FeLV-related anemia can help to determine the etiology of anemia, influencing treatment decisions (Lutz et al. 2009) of anemic FeLV-positive cats.

Although the hematological abnormalities in FIV infection are less severe than FeLV infection, they could be more evident in advanced stages of infection (Hartmann 2011). The virus replicates in monocytes, lymphocytes, and macrophages, causing changes in blood counts, but FIV infection of myeloid or erythroid progenitor cells have not been demonstrated (Gleich \& Hartmann 2009). The median hematocrit of FIV-positive anemic cats was 18\% and FIV-positive cats were $19 \%$ more likely to be anemic than FIV-negative cats. This information is in agreement with previous studies that also found that anemia, as well as neutropenia and lymphopenia, are the hematological disorders most commonly associated with this infection (Collado et al. 2012, Hartmann 2012, 2014). In FIV infection, the anemia could be related to the chronic disease caused by inflammatory opportunistic infections resulting from suppression of the immune system produced by the virus (Hartmann 2012). Other mechanisms that have been proposed include changes to the bone marrow environment and the effect of cytokines (Gleich \& Hartmann 2009).

Considering the evaluation of WBC, FeLV-positive cats were 9\% more likely to have leukopenia than FeLV-negative cats. Cytopenias in FeLV-infected cats include persistent or cyclic neutropenia and lymphopenia, which may be caused by myelosupressing syndromes such as myelodysplastic syndrome, myeloblastopenia, myelofibrosis, thymic atrophy and depletion of paracortical areas of lymph nodes (Hartmann 2011). FeLV-related leukopenia was related to lymphopenia in present study and suggest that the most of cats have the infection with the FeLV-T which is a variant of the virus with tropism for lymphocytes related with immunodeficiency in infected cats (Sykes 2010). Lymphopenia can contribute to leukopenia due to viral replication in CD4+ lymphocytes, causing inversion of the CD4/CD8 ratio in infected cats (Quackenbush et al. 1990, Hoffmann-Fezer et al. 1996), but leukopenia is mainly due to the decline in CD8+ lymphocytes (Hoffmann-Fezer et al. 1996). Another situation that may be related to lymphopenia in FeLV-infected cats is the response to stress that could be related with chronic disease, since the clinical signs of infection are continuous and debilitating (Datz 2010). One limitation of this study was the inability of differentiation in FeLV subtypes to correlate the hematologic changes with viral effect.

\section{CONCLUSIONS}

Young, anemic and lymphopenic cats are more likely to be FeLV-positive and male and anemic cats are more likely to be FIV-positive.

Hematological abnormalities such as cytopenias are more evident in FeLV infection than in FIV infection, in comparison to negative cats.

Identification of associated factors and correlation of hematological disorders with infection by retroviruses in cats can be convenient for detecting this clinical condition and suggest the testing in a cat population.

Conflict of interest statement.- The authors have no competing interests.

\section{REFERENCES}

Arjona A., Escolar H., Soto I., Barquero N., Martin D. \& Gomez-Lucia E. 2000. Seroepidemiological survey of infection by feline leukemia virus and immunodeficiency virus in madrid and correlation with some clinical aspects. J. Clin. Microbiol. 38(9):3448-3449.

Bande F., Arshad S.S., Hassan L., Zakaria Z., Sapian N.A., RAhman A.N. \& Alzawy A. 2012. Prevalence and risk factors of feline leukaemia virus and feline immunodeficiency virus in peninsular Malaysia. BMC Vet. Res. 8:33. <https://doi.org/10.1186/1746-6148-8-33>

Bandecchi P., Matteucci D., Baldinotti F., Guidi G., Abramo F., Tozzini F. \& Bendinelli M. 1992. Prevalence of feline immunodeficiency virus and other retroviral infections in sick cats in Italy. Vet. Immunol. Immunopathol. 31(3/4):337-345.

Chhetri B.K., Berke O., Pearl D.L. \& Bienzle D. 2015. Comparison of risk factors for seropositivity to feline immunodeficiency virus and feline 
leukemia virus among cats: a case-case study. BMC Vet Res. 11:30. <https://doi.org/10.1186/s12917-015-0339-3>

Collado V.M., Domenech A., Miró G., Martin S., Escolar E. \& Gomez-Lucia E. 2012. Epidemiological aspects and clinicopathological findings in cats naturally infected with feline leukemia virus (FeLV) and/or feline immunodeficiency virus (FIV). Open J. Vet. Med. 2(2):13-20.

Datz C.A. 2010. Noninfectious causes of immunosuppression in dogs and cats. Vet. Clin. N. Am., Small. Anim. Pract. 40(3):459-467.

Dunham S.P. \& Graham E. 2008. Retroviral infections of small animals. Vet. Clin. N. Am., Small Anim. Pract. 38(4):879-901.

Gleich S.E., Krieger S. \& Hartmann K. 2009. Prevalence of feline immunodeficiency virus and feline leukaemia virus among client-owned cats and risk factors for infection in Germany. J. Feline Med. Surg. 11(12):985-992.

Gleich S. \& Hartmann K. 2009. Hematology and serum biochemistry of feline immunodeficiency virus-infected and feline leukemia virus-infected cats. J. Vet. Int. Med. 23(3):552-558.

Hartmann K., Griessmayr P., Schulz B., Greene C.E., Viddyashankar A.N., Jarrett O. \& Egberink H.F. 2007. Quality of different in-clinic test systems for feline immunodeficiency virus and feline leukaemia virus infection. J. Feline Med. Surg. 9(6):439-445.

Hartmann K. 2011. Clinical aspects of feline immunodeficiency and feline leukemia virus infection. Vet. Immunol. Immunopathol. 143(3/4):190201.

Hartmann K. 2012. Clinical aspects of feline retroviruses: a review. Viruses 4 (11):2684-2710.

Hartmann K. 2014. Feline leukemia virus infection, p.108-136. In: Greene C. (Ed.), Infectious Diseases of the Dog and Cat. 4th ed. Elsevier, Missouri.

Hoffmann-Fezer G., Mortelbauer W., Hartmann K., Mysliwietz J., Thelfeld S., Beer B., Thum I. \& Kraft W. 1996. Comparison of T-cell subpopulations in cats naturally infected with feline leukaemia virus or feline immunodeficiency virus. Res. Vet. Sci. 61(3):222-226.

Hofmann-Lehmann R., Holznagel E., Ossent P. \& Lutz H. 1997. Parameters of disease progression in long-term experimental feline retrovirus (feline immunodeficiency virus and feline leukemia virus) infections: he- matology, clinical chemistry and lymphocytes subsets. Clin. Diagn. Lab. Immunol. 4(1):33-42.

Hosie M.J., Robertson C. \& Jarrett 0. 1989. Prevalence of feline leukaemia virus and antibodies to feline immunodeficiency virus in cats in the United Kingdom. Vet. Rec. 125(11):293-297.

Lee I.T., Levy J.K., Gorman S.P., Crawford P.C. \& Slater M.R. 2002. Prevalence of feline leukemia virus infection and serum antibodies against feline immunodeficiency virus in unowned free-roaming cats. J. Am. Vet. Med. Assoc. 220(5):620-622.

Levy J.K., Scott H.M., Lachtara J.L. \& Crawford P.C. 2006. Seroprevalence of feline leukemia virus and feline immunodeficiency virus infection among cats in North America and risk factors for seropositivity. J. Am. Vet. Med. Assoc. 228(3):371-376.

Linenberger M.L. \& Abkowitz J.L. 1995. Haematological disorders associated with feline retrovirus infections. Baillieres Clin. Haematol. 8(1):73-112.

Lutz H., Addie D., Belák S., Boucraut-Baroln C., Frymus T., Hartmann K., Hosie M.J., Lloret A., Marsillio F., Pennisi M.G., Radford A.D., Thiry E., Truyen U. \& Horzinek M.C. 2009. Feline leukaemia, ABCD guidelines on prevention and management. J. Fel. Med. Surg. 11(7):565-574.

Quackenbush S.L., Donahue P.R., Dean G.A., Myles M.H., Ackley C.D., Cooper M.D., Mullins J.I. \& Hoover E.A. 1990. Lymphocyte subset alterations and viral determinants of immunodeficiency disease induction by the feline leukemia virus FeLV-FAIDS. J. Virol. 64(11):5465-5474.

Scherk M.A., Ford R.B., Gaskell R.M., Hartmann K., Hurley K.F., Lappin M.R., Little S.E., Nordone S.K. \& Sparkes A.H. 2013. 2013 AAFP Feline vaccination advisory panel report. J. Fel. Med. Surg. 15(9):785-808.

Shelton G.H. \& Linenberger M.L. 1995. Hematologic abnormalities associated with retroviral infections in the cat. Semin. Vet. Med. Surg., Small Anim. 10(4):220-233.

Sykes J.E. 2010. Immunodeficiencies caused by infectious diseases. Vet. Clin. N. Am., Small Anim. Pract. 40(3):409-423.

Tvedten H. \& Moritz A. 2010. Reticulocyte and heinz body staining and enumeration, p.1067-1073. In: Weiss D.J. \& Wardrop K.J. (Eds), Schalm's Veterinary Hematology. 6th ed. Wiley-Blackwell, Ames. 